\title{
The Effect of Economic Resilience on Private Investment in Selected Malaysian Economic Sectors
}

\author{
Sallahuddin Hassan \\ Zalila Othman
}

Department of Economics and Agribusiness, School of Economics, Finance and Banking, UUM COB Universiti Utara Malaysia, Malaysia; E-mail: din636@uum.edu.my

\section{Doi:10.5901/mjss.2015.v6n6p374}

\begin{abstract}
Malaysia is a small open economy and is exposed to all sorts of external shocks, interruptions, disruptions or macroeconomic uncertainty. These shocks may cause many potential misfortunes such as periodic economic recessions, fluctuation in the business cycles, unpredictable oil price hikes, financial crises, technological change, crime and natural disasters. The objective of this paper is to analyse the effect of economic resilience on private investment in selected Malaysian economic sectors. The analysis uses secondary panel data that are gathered from various official reports through library research. In the analysis, private investment in selected Malaysian economic sectors represents the dependent variable. Meanwhile, the independent variables are represented by gross domestic product (GDP), interest rates, macroeconomic stability and microeconomic market efficiency. The indicator used to represent macroeconomic stability is fiscal deficit to GDP ratio. Microeconomic market efficiency is represented by government size (government expenditure), regulatory efficiency (business freedom), and market openness (investment freedom). The empirical analysis has been performed using generalized methods of moments (GMM). The results show that GDP, interest rates, and investment freedom are statistically significant at the five percent level of significance.
\end{abstract}

Keywords: Private investment, economic resilience, generalized methods of moments

\section{Introduction}

Malaysia is a small open economy and is easily exposed to all sorts of exogenous shocks, interruptions, disruptions or macroeconomic uncertainty. Exogenous shocks, which mainly consist of natural shocks and external shocks, may cause many potential misfortunes and instability on growth such as periodic economic recessions, fluctuation in the business cycles, unpredictable oil price hikes, financial crises, technological change, crime and natural disasters. Traditional macroeconomic theories view that private investment is influenced by many conventional determinants or financial factors namely interest rates, marginal efficiency of capital, and price of capital. Our survey of the literature shows that previous studies have not provided sufficient evidence on the relationship between private investment and economic resilience.

As shown by Figure 1, private investment has significantly increased during the past two decades after showing a constant trend during the 1960s and 1970s. Starting in 1987, the level of private investment consistently increased until Malaysia achieved its highest level of private investment in 1997. After that, private investment level dramatically declined followed by short-run fluctuations after 1999. 


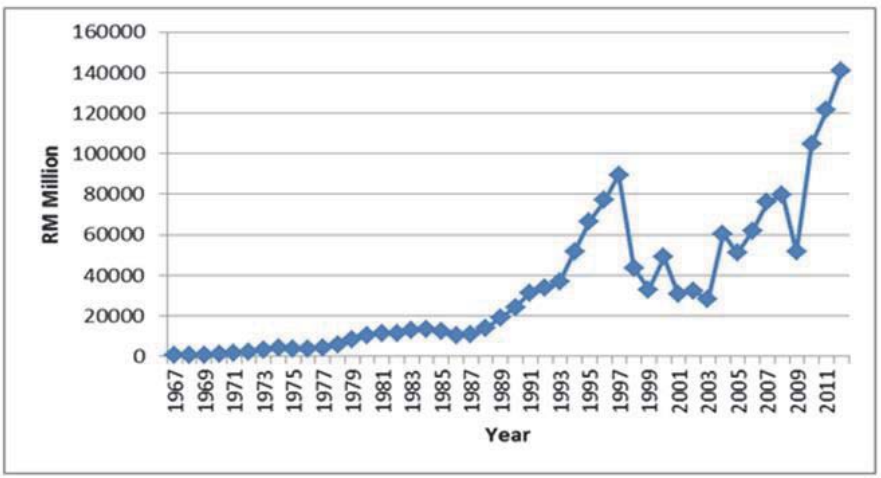

Figure 1: The Trend of Private Investment in Malaysia, 1995 - 2012

By observing the trend of private investment in the past four decades, it seems that the private sector is able to absorb exogenous shocks, particularly the 1997 Asian financial crisis, and to encounter various kinds of market problems either caused by internal or external events. In addition, the government has also succeeded in encouraging private investment through various government efforts such as promoting entrepreneurship, export promotion, investment promotion, and financial incentive for investment.

Furthermore, Figure 2 shows the trend of private sector investment in the agriculture, industry and trade, transport and communication, and construction sectors in Malaysia. For the agriculture sector, from 1995 to 1999, there were small but steady increases in private investment. However, it suffered a slight drop in 2000 but has been stable from then until 2012. For industry and trade, there were large fluctuations from 1995 to 2005 but from 2006 to 2012, it has been on an upward trend. Meanwhile, there were small short term fluctuations from 1995 to 2003 in the transport and communication sector. However, it has been on an increasing trend from 2003 until 2012. As for the construction sector, private investment has steadily increased from 1995 but then dropped sharply in 2006 but has been stable from then to 2012.

According to Guillaumont (2009), while private investment is sensitive to many exogenous shocks, it also however, possesses resilience or has the capacity to react to shocks. Nevertheless, empirical evidence that prove the relationship between economic resilience and private investment are relatively very limited because less attention has been accorded to the issue. Thus, we intend to fill the gap that exists in the literature, to provide a clear picture of the consequences of resilience on investment activities, and to foster interest among researchers to examine the broader macroeconomic perspective of economic resilience.

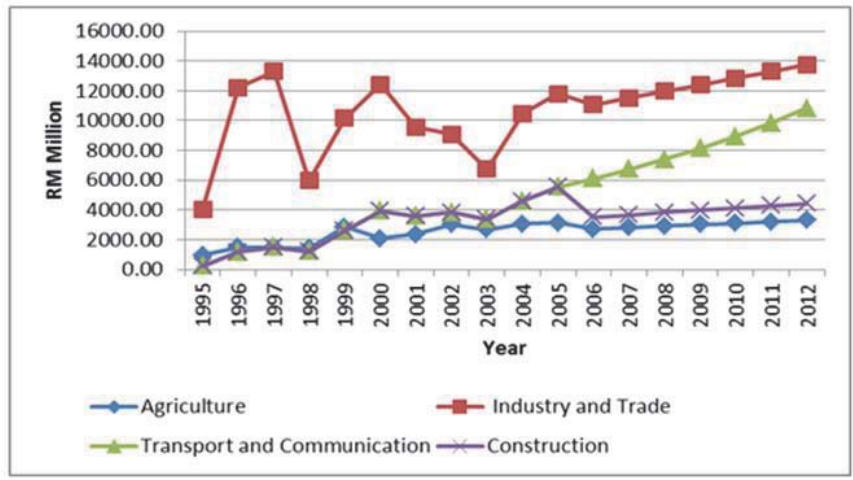

Figure 2: The Trend of Private Investment in Selected Economic Sector of Malaysia, 1995 - 2012

Therefore, this paper focuses exclusively on empirically analysing the effect of economic resilience on private investment 
in selected Malaysian economic sectors from a macroeconomic perspective. The remainder of the paper is organized as follows: A brief literature review is discussed in Section 2 followed by the research methodology in Section 3 . Section 4 presents the discussion of the empirical results and Section 5 presents the policy implication and conclusion.

\section{Literature Review}

The term "resilience" was originally described by Elton (1958) as the amplitude changes brought about by disturbances and by the dynamics of post-disturbance recovery. Then, the term was popularized by Holling (1973) within the broader framework of 'ecosystem stability'. Later, the term resilience was defined in many different ways and dimensions in different disciplines such as social science, ecology, economics, geography, regional studies, engineering, and other social sciences. From a macroeconomic perspective, in particular, resilience means the capacity and ability of an economic system to cope with external shocks such as structural changes caused by global or domestic competition and other external shocks such as natural disasters and wars. The economic literature are generally concerned about the degree to which a national economy is able to return to its previous level and/or growth rate of output, employment, or population is restored after experiencing an external shock (Blanchard \& Katz, 1992; Briguglio et al., 2006; Cellini \& Torrisi, 2014; Feyrer et al., 2007; Rose \& Liao, 2005). However, Holling (2001) argued that the concept of resilience does not necessarily imply a return to the pre-existing state, but could be referred to as the ability to respond to opportunities which arise as a result of change.

Even though the body of literature which focuses on conceptualizing and measuring economic resilience has grown considerably, most of the studies however, have only vigorously debated over the conceptual definitions, research methodology, and theoretical significance of resilience. In terms of conceptual definition, Briguglio et al. (2009) stated that economic resilience signifies the policy-generated ability of an economy to adjust to the negative impacts of adverse exogenous shocks and to benefit from positive shocks.

In terms of empirical evidence, most of the studies show that resilience has an indirect effect on the real sector. Certain studies have provided evidence that resilience has a significant impact on real activities, such as economic growth (i.e. Briguglio et al., 2006; Duval \& Vogel, 2008; Hill et al., 2011; and Simmie \& Martin, 2010), private investment (i.e. Bhaskaran, 2007; Dawe, 1996; Guillaumont, 2009), and employment (i.e. Fingleton et al., 2012; Besser, 2013). In addition to a conceptual and empirical framework development for analysing and measuring economic resilience, Briguglio et al. (2006) provided evidence on the significant effect of resilience on GDP. Similarly, Duval and Vogel (2008), Hill et al. (2011), and Simmie and Martin (2010) explained why a number of inherently resilient countries have attained relatively high level of GDP per capita. Ramey and Ramey (1995) have shown a significant relationship between the instability of the actual or average rate of economic growth and economic resilience. Meanwhile, by looking at the quality of life of disaster-shocked towns and comparing that with those of the non-disaster-shocked town, Besser (2013) found that economic resilience is capable in maintaining the level of quality of life of the community and minimises major employment loss after natural disaster shocks.

There are considerably very few and limited previous studies which specifically aimed at empirically identifying and explaining the effect of economic resilience on private investment. Since there are very few empirical studies in this area, the linkages between resilience and private investment are thus unclear. However, the studies by Bhaskaran (2007), Dawe (1996) and Guillaumont (2009) can be used as reference to justify their linkage. The study by Bhaskaran (2007) has actually indirectly explained the effect of economic resilience on private investment. In his study, Bhaskaran has discussed seven internal factors that have shaped a healthy economy resilience of the South East Asian economies in 2006. Those internal factors are consumer spending, oil price shock, political stability, government policies, undercontrolled inflation, financial stability, and economic stability. He has stated that the year 2006 marked the improvement in economic stability and resilience towards external and internal shocks for the South East Asian economies. For instance, an oil price shock causes deterioration of the currency, interest rate and inflation, which subsequently weakened economic resilience. Specifically, an oil price shock causes an increase in the interest rate, which will result in a decline in private investment.

Furthermore, Dawe (1996) examined the effect of export instability as an indicator of trade shock, on investment and growth. Export instability results from some exogenous occurrences such as variability in world prices, external demand and domestic events that are not policy-related. By referring to a large sample of countries, Dawe's empirical results have indicated that export variability was positively correlated with investment but negatively linked with growth during the period from the early 1970 s to the mid-1980s. His study is supported by Guillaumont (2009). Guillaumont argued that non-resilient economy exists if a country faces various primary and intermediate economic instabilities such as instability in export, investment rate, and relative prices. For instance, investment rate instability is the result of a 
declining marginal productivity of investment. Thus, it seems that external instability causes negative effects on investment level through interest rate instability.

\section{Methodology}

Secondary panel data analysis has been performed to examine the effect of economic resilience on private investment. The data set was constructed from four selected economic sectors in Malaysia namely agriculture, industry and trade, transport and communication, and construction covering the period $1995-2013$. The selection of the sectors and the period of study were based on data availability. Data were gathered from various official government reports through library research.

To examine the role played by economic resilience on private investment, our model has been developed based on the famous firm investment decision models such as the accelerator model, Jorgenson's neoclassical model, and the modified neoclassical model (i.e. Clark, 1979; Bernanke, Bohn \& Reiss, 1988; Jorgenson et al., 1970a, b). Equation [1] is the model used in the regression panel analysis of private investment.

[1] $P R I_{i t}=\beta_{0}+\beta_{1} G D P_{i t}+\beta_{2} I N T_{i t}+\beta_{3} F D G D P R_{i t}+\beta_{4} G I N V_{i t}+\beta_{5} B F_{i t}+\beta_{6} I N V F_{i t}+\varepsilon_{i t}$

where $i=1,2,3,4, t=1,2, \ldots, 19$ years, $\beta_{i}$ represents the coefficients and $\varepsilon_{i}$ is the error term. In Equation [1], the dependent variable is represented by private investment in selected Malaysian economic sectors. Meanwhile, the independent variables are represented by gross domestic product (GDP), interest rates (INT), macroeconomic stability and microeconomic market efficiency. The variable used to represent macroeconomic stability is fiscal deficit to GDP ratio (FDGDPR). Microeconomic market efficiency is represented by government size (government investment - GINV), regulatory efficiency (business freedom - BF), and market openness (investment freedom - INVF). These indicators, developed by Briguglio et al. (2009) and the Heritage Foundation Index of Economic Freedom, are included in Equation [1] to capture the effect of economic resilience on private investment.

To investigate empirically the effects of economic resilience on private investment in the four main economic sectors, generalized methods of moments (GMM) proposed by Hansen (1982) and Hansen and Singleton (1982) have been employed in the empirical analysis. GMM, as a dynamic panel data model, has significant advantages over other methods such ordinary least squares (OLS) and maximum likelihood (ML). In contrast to OLS, this method can correct for unknown forms of autocorrelation and heteroskedasticity (Cragg, 1983). Autocorrelation problem occurs due to the presence of lagged dependent variables among the regressors. Meanwhile, heteroscedasticity problem exists due to individual effects characterizing the heterogeneity among the sectors. Thus, the standard errors based on GMM will be different from the OLS estimates. Nason and Smith (2008) have pointed out that the parameters estimated using GMM estimation are consistent under weak distributional assumptions and more efficient. Meanwhile, Wooldridge (2001) has argued that parameters estimated under OLS will be unbiased as well as consistent under distributional assumptions. Wooldridge (2001) further argued that GMM allows for more moment conditions than there are parameters to estimate. Furthermore, GMM can take into account potential biases due to unobserved sector-specific effects (Bond et al., 2003), omitted variables (Nili \& Rastad, 2007) as well as simultaneity bias (Levine, 1998). Levine (1998) used GMM estimators to account for simultaneity bias for the sample of 44 developed and developing countries in his study. Pindado and de la Torre (2008) pointed out that GMM allows us to control for the problem of endogeneity by using instruments. If the endogeneity issue is ignored, a spurious correlation between private investment and the right-hand side variables will be obtained. Thus, the advantages of GMM would seem to provide a strong argument for using it.

In implementing an optimal GMM estimation, the Newey-West (1987) method has been employed to obtain a matrix of the GMM parameter estimates that is robust to autocorrelation and heteroskedasticity. To be valid as instrument variables, it is assumed that the variables used in the estimation are not correlated with the error terms. In the estimation, instrument variables, all right-hand side variables and predetermined variables are restricted to lags of up to 2 periods, or $t-1$ and $t-2$ only.

\section{Discussion of Results}

Table 1 reports the contemporaneous correlation coefficients results among the variables. As seen in the table, the correlation coefficients are all positive. The highest correlation is between $P R I$ and GDP, followed by between PRI and INVF. The results indicate that all the right-hand side variables encourage private investment. 
Table 1: Correlation Coefficient among Variables

\begin{tabular}{cccccc}
\hline Variable & PRI & GDP & GINV & INVF & BF \\
\hline$P R I$ & 1.000 & 0.732 & 0.534 & 0.683 & 0.548 \\
GDP & & 1.000 & 0.472 & 0.379 & 0.332 \\
GINV & & & 1.000 & 0.097 & 0.301 \\
INVF & & & & 1.000 & 0.673 \\
BF & & & & & 1.000 \\
\hline
\end{tabular}

The results of the estimation are tabled in Table 2. The results show that all the coefficients of GDP, GINV, INVF and BF are statistically significant at the five percent level of significance. Thus, the results are consistent with our earlier expectation. Specifically, the effect of GINV, INVF and BF have been to raise the level of private investment by, on average, 268, 88 and 94 percentage points, respectively. For instance, we find a positive coefficient for investment freedom, which confirms that more freedom in the investment environment encourages more private investment. In particular, the positive relationship between private investment and economic resilience indicates that the level of private investment increases as a consequence of the economy being able to return to its previous level and/or growth rate of output. This could be explained by the fact that healthy economic resilience increases private investment. The findings are actually consistent with Bhaskaran (2007), who suggested that weak economic resilience will result in declining private investment.

Table 2: GMM Estimation Results

\begin{tabular}{|c|c|c|c|c|}
\hline Variables & Coefficient & Standard Error & t-stat & $\operatorname{Prob}(t)$ \\
\hline$C$ & -14938.630 & 10294.650 & -1.451 & 0.152 \\
\hline GDP & 0.070 & 0.008 & 8.750 & $0.000^{*}$ \\
\hline GOVS & 267.696 & 124.586 & 2.149 & $0.001^{*}$ \\
\hline INVF & 88.407 & -43.155 & 2.049 & $0.000^{*}$ \\
\hline$B F$ & 94.297 & 47.216 & 1.997 & $0.045^{\star}$ \\
\hline \multicolumn{5}{|l|}{ Diagnostic statistics: } \\
\hline Wald test of joint significance ( $p$-value) & $0.000^{*}$ & & & \\
\hline Sargan test (J- statistics) & 36.512 & & & \\
\hline ( $p$-value) & $(0.000)^{*}$ & & & \\
\hline 1st-order serial correlation ( $p$-value) & $0.000^{*}$ & & & \\
\hline $2^{\text {st-order serial correlation ( } p \text {-value) }}$ & 0.276 & & & \\
\hline Number of observations & 64 & & & \\
\hline Number of sectors & 4 & & & \\
\hline
\end{tabular}

The diagnostic statistics support the chosen specification. The Wald test is used for the joint significance of the estimated coefficients. Since its $p$-value is less than five percent, the difference between the two coefficients is thus highly statistically significant. Furthermore, the Sargan test of over-identifying restrictions is employed to test the validity of the instrument variables. As a matter of fact, the result shows no evidence against the validity of the instruments. The same purpose can also be achieved using the tests for first- and second-order serial correlation of the residuals, which are asymptotically distributed as standard normal variables (Arellano \& Bond, 1991). The results of the tests only reveal strong first-order autocorrelation of the residuals.

\section{Policy Implication and Conclusion}

The results indicate that the expansion of private investment significantly rely on economic resilience. It means that the more resilient the Malaysian economic structure is, the higher private investment will be. Therefore, Malaysia's economic resilience needs to be strengthened in order to avoid economic vulnerability and encourage private investment. In this regard, economists have agreed that the strength of macroeconomic policies, either fiscal or monetary or both, is one of the important determinants of stronger economic resilience to various external and internal shocks. Fiscal policy, for instance, may affect resilience pattern via two main channels, automatic stabilizers and discretionary fiscal policy. Automatic stabilizers which typically are associated with large public sectors are expected to diminish the impact of shocks (Ahrend et al., 2006). Furthermore, Sutherland and Hoeller (2014) have also recommended that long-growth 
promoting government macroeconomic policies can lessen vulnerability and boost economic resilience of an economic structure to macroeconomic shocks. Thus, achieving economic resilience should be one of the overriding objectives of the implementation of long-growth promoting government macroeconomic policies in Malaysia. These policies should put greater emphasis on longer term goals, such as using the strategy of anti-cyclical wage policy (Aiginger, 2009).

Government policies as autonomous policy shocks should consider both international and national dimensions to function as an effective reaction to various shocks. As suggested by Aiginger (2009), the economic strategies need to be part of international strategies in order to reduce the negative effects of shocks. As an autonomous policy shock, a current government policy can influence economic resilience and is detrimental to economic development. Thus, the government needs to implement better macroeconomic policies such as strengthening the economic structure, diversifying the sectoral structure, improving the taxation structure, and stabilizing the institutional framework. Among the strategies to extensively diversify the sectoral structure of Malaysia to increase resilience, for example, are establishing a broad spread of exports activities across sectors, upgrading the industrial structure, improving the agricultural sector, and strengthening the services sector. These strategies can be implemented using cluster-based economic development policies (Turner, 2001; Desrochers \& Sautet, 2004). In fact, this strategy can play a role as a stabilizer and is an important tool for achieving high economic growth because it can actually help the Malaysian government to anchor a smaller size of exogenous shocks, to reduce the persistence of the impact of shocks, to promote economic stability, and finally to strengthen economic resilience. In addition, Combes et al. (2000) and Easterly et al. (2001) have provided clear empirical evidence of the influence of government policies on the volatility of growth rates, and it has become one of the prominent indicators of economic resilience. Therefore, a good, adequate and effective macroeconomic policy structural setting is inevitable and crucial because these policies should be capable of minimizing the impact of shocks and expediting the economy recovery. Government policies should be able to promote long-term resilience and to increase the competitiveness of private investment.

This paper has successfully examined empirically the effect of economic resilience on private investment in four selected economic sectors in Malaysia. The findings have shown that there is clear empirical evidence that economic resilience has important impacts on private investment in the selected economic sectors. Macroeconomic stability and microeconomic market efficiency are considered to be the two main strategies for establishing a resilient economy that significantly encourages private investment. In fact, both components are likely to be highly influenced by effective longgrowth promoting government macroeconomic policies and comprehensive institutional framework, which can diminish the impact of common shocks and increase the stabilizing effect.

\section{Acknowledgments}

We are grateful for the financial support from Ministry of Education of Malaysia under RAGS research grant 12717 for this research undertaking.

\section{References}

Ahrend, R. Catte, P. and Price, R. (2006), Interactions between Monetary and Fiscal Policy: How Monetary Conditions Affect Fiscal Consolidation, OECD Economics Department, Working Paper, No. 521.

Aiginger, K. (2009). Strengthening the resilience of an economy: Enlarging the menu of stabilisation policy to prevent another crisis. Intereconomics, 44(5), $309-316$.

Arellano, M. \& Bond, S. (1991). Some tests of specification for panel data: Monte Carlo evidence and an application to employment equations. Review of Economic Studies, 58, $277-297$.

Bhaskaran, M. (2007). The regional economies a year of growth, stability and resilience. Southeast Asian Affair, 29(3), 32 - 58.

Bernanke, B., Bohn, H. \& Reiss, P.C. (1988). Alternative non-nested specification tests of time-series investment models. Journal of Econometrics, 37, $293-326$.

Besser, T. (2013). Resilient small rural towns and community shocks. Journal of Rural and Community Development, 8(1), 117 - 134.

Blanchard, O.J. \& Katz, L.F. (1992). Regional evolutions. Brookings Papers on Economic Activity, 1, 1 - 75.

Bond, S., Elston, J.A., Mairesse, J. \& Mulkay, B. (2003). Financial factors and investment in Belgium, France, Germany, and the United Kingdom: A comparison using company panel data, The Review of Economics and Statistics, 85(1), $153-165$.

Briguglio, L, Cardina, G., Bugeja, S. \& Farrugia, N. (2006), Coceptualizing and measuring economic resilience. Working Paper, Economic Department, University of Malta.

Briguglio, L., Cardina, G., Farrugia, N. \& Vella, S. (2009). Economic vulnerability and resilience: Concepts and measurements. Oxford Development Studies, 37(3), 229 -247.

Cellini, R. \& Torrisi, G. (2014). Regional resilience in Italy: A very long-run analysis, Regional Studies. 48(11), 1779 - 1796.

Clark, P.K. (1979). Investment in the 1970s: Theory, performance and prediction. Brookings Papers on Economic Activity, 1, 73 - 113. 
Combes, J-L. \& Guillaumont, P. (2000). Commodity price volatility, vulnerability and development. Development Policy Review, 20(1), $25-39$.

Cragg, J.G. (1983). More efficient estimation in the presence of heteroskedasticity of unknown form. Econometrica, 51, $751-763$.

Dawe, D. (1996). A new look at the effects of export instability on investment and growth. World Development, 24(12), $1905-1914$.

Desrochers, P. \& Sautet, F. (2004). Cluster-besed economic strategy, facilitation policy and the market process. The Review of Austrian Economics, 17(2/3), $233-245$.

Duval R. \& Vogel, L. (2008), Economic resilience to shocks: The role of structural policies. OECD Journal Economic Studies, 2008, 201 $-238$.

Elton, C.S. (1958). The ecology of invasions by animals and plants. London: Methuen.

Easterly, W., Islam, R. \& Stiglitz, J. (2001). Shaken and stirred: Explaining growth volatility, in Pleskovic, B. \& Stern, N., eds, Annual World Bank Conference on Economics Development, 191 - 211, The World Bank.

Feyrer, J., Sacerdote, B. \& Stern, A.D. (2007). Did the rust belt become shiny? A study of cities and counties that lost steel and auto jobs in the 1980s in Brookings-Wharton Papers on Urban Affairs 2007, edited by Gary Burtless and Janer Rothernberg Pack, 41 -102 . Brooking.

Fingleton, B., Garretsen, H, \& Martin, R. (2012). Recessionary shock and employment: Evidence of resilience of U.K. regions. Regional Science, 52, $109-133$.

Guillaumont, P. (2009). An economic vulnerability index: Its design and use for international development policy. Oxford Development Studies, 37(3), $193-228$.

Hansen, L.P. (1982). Large sample properties of generalized method of moments estimators. Econometrica, 50, $1029-1054$.

Hansen, L.P. \& Singleton, K.J. (1982). Efficient estimation of asset pricing models with moving average errors (mimeo).

Holling, C.S. (1973). Resilience and stability of ecological systems. Annual Review of Ecology and Systematics, 4, 1 - 23.

Holling, C.S. (2001), Understanding the complexity of economic, ecological and social system. Ecosystem, 4, 390 - 405.

Hill, E., St. Clair, T., Wial, H., Wolman, H., Atkins, P., Blumenthal, P., Ficenec, S. \& Friedhoff, A. (2011). Economic shocks and regional economic resilience. Working Paper 2011-13. Berkeley: Building Resilient Regions, Institute of Governmental Studies, University of California.

Jorgenson, D.W., Jerald, H. \& Nadiri, M.I. (1970a). A comparison of alternative econometric models of quarterly investment behavior. Econometrica, 38, $187-212$.

Jorgenson, D.W., Jerald, H. \& Nadiri, M.I. (1970b). The predictive performance of econometric models of quarterly investment behavior. Econometrica, 38, $213-224$.

Levine, R. (1998). The legal environment, banks, and long run economic growth. Journal of Money, Credit, and Banking, 30, 596 - 613.

Nason, J.M. \& Smith, G.W. (2008). The new Keynesian Phillips curve: Lessons from single-equation econometric estimation. Federal Bank of Richmond Economic Quarterly, 94(4), 361 - 395.

Newey, W.K. \& West, K. (1987). A simple, positive, semi definite, heteroskedasticity and autocorrelation consistent covariance matrix. Econometrica, 55, $703-708$.

Nili, M. \& Rastard, M. (2007). Addressing the growth failure of the oil economies: The role of financial development. The Quarterly Journal of Economics and Finance, 46, $726-740$.

Pindado, J. \& de la Torre, C. (2008). Financial decisions as determinants of ownership structure: Evidence from Spanish family controlled firms. Managerial Finance, 34(2), 868 - 885.

Ramey, G. \& Ramey, V. (1995). Cross country evidence on the link between volatility and growth. The American Economic Review, $85(5), 1138-1151$.

Rose, A. \& Liao, S-Y. (2005). Modeling regional economic resilience to disasters: A computable general equilibrium analysis of water service disruptions. Journal of Regional Science, 45, 75 - 112.

Simmie, J. \& Martin, R. (2010). The economic resilience of regions: Towards an evolutionary approach. Cambridge Journal of Regions, Economy and Society, $3(1), 27-43$.

Sutherland, D. and Hoeller, P. (2014). Growth policies and macroeconomic stability. OECD Economic Policy Papers, 8, 1- 30.

Turner, R.C. (2001). A framework for cluster-based economic development policies. 1 - 39. The Nelson A. Rockefeller Institute of Government, New York: USA..

Wooldridge, J.M. (2001). Applications of generalized method of moments estimation. The Journal of Economic Perspectives, 15(4), 87 100. 